\title{
THE EFFECT OF WORKING ENVIRONMENT ON THE TEACHER PERFORMANCE
}

\author{
Baharuddin \\ Universitas Islam Negeri Alauddin Makassar, Fakultas Tarbiyah dan Keguruan \\ Jalan H.M. Yasin Limpo No. 36, Samata-Gowa \\ Email: baharuddinjepot@gmail.com
}

\begin{abstract}
:
This research aims to investigate the effect of the working environment on teachers' performance at MTS Madani Pao-Pao. This research used Quantitative Approach with the Ex-post Facto type. The sample was 12 teachers selected using purposive sampling. The data were collected through a questionnaire with the Likert Scale and then analyzed using descriptive and inferential analyses. The finding indicated a significant influence between the work environment and the teachers' performance. Therefore, the conducive, comfortable, safe, and enjoyable working environment affected the teachers' performance at MTS Madani Pao-Pao. The implication of this research is to inform the principal or leadership to provide a conducive, comfortable, and safe working environment to improve the teachers' performance.
\end{abstract}

\begin{abstract}
Abstrak:
Penelitian ini bertujuan untuk mengetahui pengaruh lingkungan kerja terhadap kinerja tenaga pendidik di MTs Madani Pao-Pao. Penelitian ini menggunakan Pendekatan Kuantitatif dengan tipe Ex-post Facto. Sampelnya adalah 12 guru yang dipilih dengan menggunakan purposive sampling. Pengumpulan data dilakukan melalui kuesioner dengan Skala Likert kemudian dianalisis menggunakan analisis deskriptif dan analisis inferensial. Hasil penelitian menunjukkan adanya pengaruh yang signifikan antara lingkungan kerja dengan kinerja tenaga pendidik. Oleh karena itu, lingkungan kerja yang kondusif, nyaman, aman, dan menyenangkan mempengaruhi kinerja para guru di MTs Madani Pao-Pao. Implikasi dari penelitian ini adalah menginformasikan kepada kepala sekolah atau pimpinan untuk menyediakan lingkungan kerja yang kondusif, nyaman, dan aman untuk meningkatkan kinerja guru.
\end{abstract}

\section{Keywords:}

Teacher Performance, Working Environment

How to Cite: Baharuddin. (2021). The Effect of Working Environment on the Teacher Performance. Lentera Pendidikan :Jurnal Ilmu Tarbiyah dan Keguruan, 24(1), 122-130. https://doi.org/10.24252/lp.2021v24n1i12.

\section{INTRODUCTION}

Teachers' performance has an essential role in the teaching and learning process. According to Bernardin and Russel (2010), performance is defined as the record of outcomes produced on a specified job function or activity during a specified period. In addition, Sardiman (2011) said that performance could be interpreted as a person's success in conducting a job obtained from his actions. Simanjuntak (2003) also stated 
that performance is the level of achievement of results for implementing specific tasks. Meanwhile, Mangkunegara (2004) explained that performance results from work in quality and quantity achieved by a teacher in performing his/her duties following the responsibilities assigned to him/her.

Several factors affected the performance of teachers as follows: (1) reward, (2) safety, (3) interpersonal relationships, (4) working environment conditions, (5) opportunities for self-development and improvement (Muhammad Surya, 2004). Based on this opinion, it indicated that one of the factors supporting the creation of productive and professional teacher performance is to create a conducive working environment.

Schultz's in Kuncoro and Dardiri (2017) stated that the problems of the working environment, including working conditions, physical conditions, and psychological conditions, were always highlighted as the contributing factor to teachers' poor performance to deliver lessons. It meant that the working environment was one of the factors that contributed to the poor performance of teachers in the teaching and learning process. A conducive working environment could provide comfort and safety for teachers at work and remain productive. In addition, Mangkunegara (2004) said that teachers in educational institutions could maximize their performance supported by an appropriate working environment.

According to Sedarmayanti (2011), the working environment is the entire tool and material faced, the surrounding environment where a person works, his/her work methods, and work arrangements both as individuals and groups. Handayani (2017) stated that a working environment is where teachers carry out activities every day. Furthermore, it is said that a sense of security and emotional stability allows teachers to work optimally. Therefore, the working environment must be conducive to create a sense of security. If teachers like the environment in which they work, they will feel comfortable at work. They can also conduct activities effectively, so that productivity will be high, and have an impact on high performance.

Suwatno \& Priansa (2011) stated the factors that affect the working environment generally consist of the physical and the psychological working environment. Physical environmental factors are the environment around the teachers themselves. Conditions in the working environment can affect teachers' satisfaction which includes (1) workspace plans, (2) job designs, (3) working environment conditions and, (4) Visual Privacy and Acoustical Privacy levels. Meanwhile, Psychological-environmental factors are matters relating to social and organizational relationships. Psychological conditions that affect teachers' satisfaction are (1) excessive work, (2) poor supervision system, (3) frustration, (4) changes in all forms and, (5) disputes between individuals and groups. In addition, Sedarmayanti (2011) divided the working environment into two types which are: Physical working environment which is including lighting/light, air temperature, humidity, air circulation, noise, mechanical adjustments, unpleasant odours, colour arrangement, decoration, music and safety in the workplace; and Non-physical working environment which is including social relationships at work between superiors and subordinates or relations between subordinates. 
In the relationship between the working environment and the performance of teachers, several research results were described. Fraenken and Wallen (2009) found that lack of good physical conditions reported that relate to our study are elevated noise levels, high levels of chalk dust, lack of good ventilation and aeration, and low lighting in the rooms where workplaces, similarly, have an adverse effect on the performance of the teachers in their line of duty. Rahmawanti, Swasto, and Prasetya (2014) found that, partially, the physical working environment significantly affects teacher performance. Simultaneous test results show that the physical working environment and non-physical working environment significantly influence teacher performance. Contrary to the results of this study, in her findings, Handayani (2017) revealed a positive and significant influence between education and training, motivation, and working environment on performance. However, partially the working environment had no significant effect on teacher performance of State Vocational High School in Banyuasin Regency.

Although there are several different findings, a theory is taken from Robbins (2002), which states that the environment can affect teacher performance in his book. Teachers pay great attention to their working environment, both in terms of personal comfort and the ease of doing a good job. The working environment, both in terms of physical and non-physical, also contributes to teacher performance.

Madani Pao-Pao consists of four educational levels; Raudhatul Athfal or RA (Islamic Kindergarten), Madrasah Ibtidaiyyah or MA (Islamic Elementary School), Madrasah Tsanawiyah or MTs (Islamic Junior High School), and Madrasah Aliyah or MA (Islamic Senior High School). This study only focused on MTs. Based on preliminary observations, the teachers and the educational staffs shared an office room. There was only a laboratory used by the students of MI, MTs, and MA Madani Pao-Pao. The facilities and infrastructure were still lacking. The classrooms were not very supportive and are also randomly used among VII, VIII, and IX grades for the students in MTs. Based on this description, the researchers were interested in conducting research relating to the effect of the working environment on the teachers' performance at MTs Madani Pao Pao. The study's objective was to investigate the effect of the physical and psychological working environment of MTs on the teachers' performance because it could make teachers professional in the implementation of learning and give positive outcomes to students.

\section{RESEARCH METHOD}

This research was quantitative research using the Ex-post Facto type. This research was located at MTs Madani Pao-Pao, Gowa Regency. The population in this study was 23 teachers at MTs Madani Pao-Pao. In this study, the researchers used the purposive sampling technique, which took samples from members of a population as representatives, which was done as intentional selection based on their ability to elucidate a specific theme, concept, and phenomena. Finally, there were 12 people selected as a sample.

The instrument used was a questionnaire. The questionnaire's statements were 
based on the independent variable (X), the working environment, and the dependent variable $(\mathrm{Y})$, teacher performance. The indicators measured included: 1) Working environments relating school physical environments such as facilities and learning resources; and non-psychological environment such as relation among headmaster, teachers, students, and teaching staffs, and the atmosphere of teaching and learning activities; and 2) Teacher performance relating the implementation of learning programs and responsibility to manage learning interactions. The questionnaire assessment used the Likert scale. Then, the data obtained from this instrument were analyzed using descriptive, inferential, and regression analyses.

\section{RESULTS AND DISCUSSION}

\section{The Effect of Working environment on the Teachers' Performance at MTs Madani Pao-Pao}

The analysis indicated that $58 \%$ of the respondents rated the working environment at MTs Madani Pao-Pao to be in the medium category. While $25 \%$ of respondents considered it to be in a low category and 17\% of respondents rated the working environment at MTs Madani Pao-Pao in the high category.

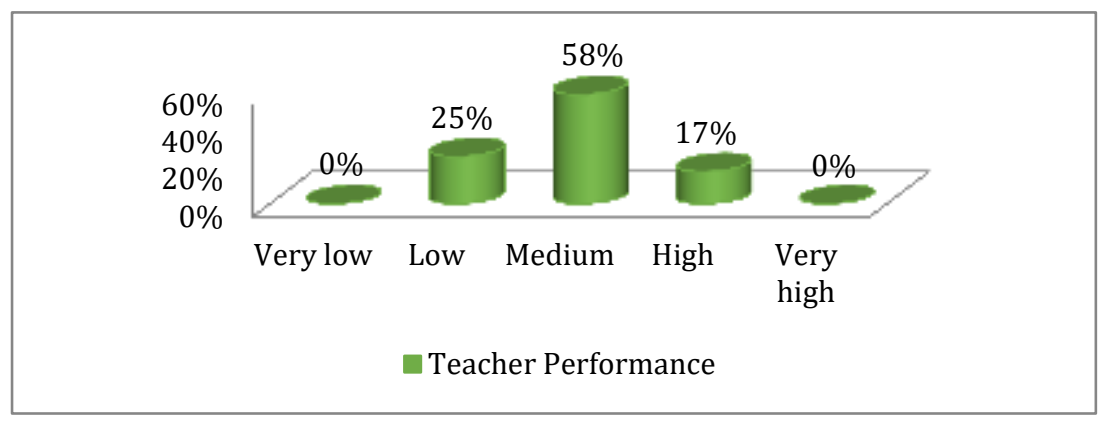

Figure 1. Working Environment of MTs Madani Pao-Pao

The categorization of the teachers' performance showed that $9 \%$ of respondents rated teachers' performance at MTs Madani Pao-Pao as still low. In comparison, $66 \%$ of respondents rated teachers' performance at MTs Madani Pao-Pao in the medium category, and $25 \%$ of respondents rated teachers' performance in the high category.

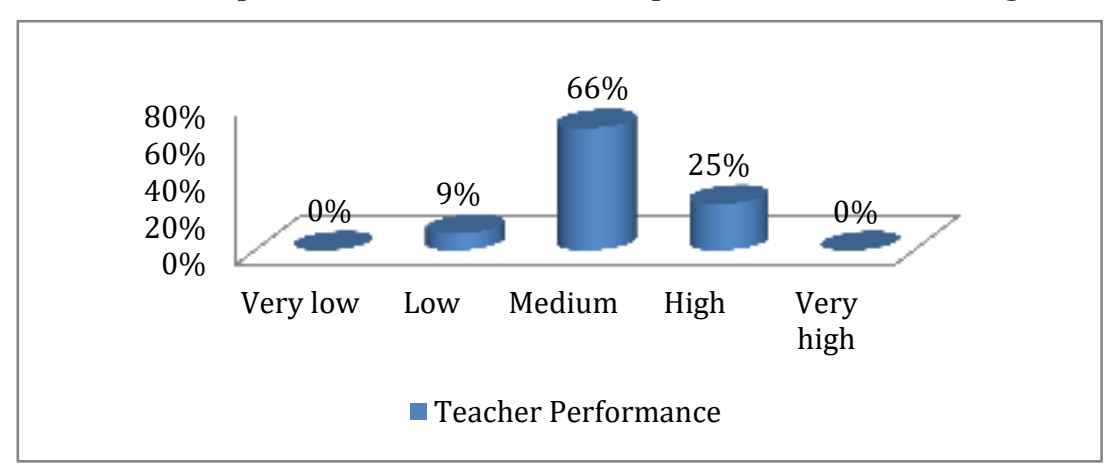

Figure 2. Teacher Performance of MTs Madani Pao-Pao 
The results of simple regression analysis indicated that the working environment positively affected the teachers' performance. The results can be seen in the following table.

Table 1. Hypothesis Test

\begin{tabular}{ccc}
\hline \multicolumn{3}{c}{ Model Summary } \\
\hline $\mathbf{R}$ & R Square & Sig. F Change \\
\hline $0.850^{\mathrm{a}}$ & 0,723 & 0,000 \\
\hline
\end{tabular}

*Source: Processed with SPSS, 2020

The hypothesis test results using SPSS were obtained $\left(\mathrm{R} / \mathrm{r}_{\mathrm{xy}}\right)=0.850$ and $\mathrm{t}_{\text {test }}=$ 26.146 with a sig. value $=0.000<0.05$. it indicated that $\mathrm{H}_{0}$ was rejected and $\mathrm{H}_{1}$ was accepted, meaning that the $\mathrm{X}$ and $\mathrm{Y}$ correlation coefficients are significant or the working environment has a significant and positive influence on teachers' performance. The value of $\mathrm{R}$ was 0.85 , close to 1 , meaning that the relationship between variable $\mathrm{X}$ (working environment) and variable $Y$ (teachers' performance) was solid and unidirectional. If the value of the working environment were higher, the value of the teachers' performance would also be higher. The value of R Square was 0.723 , which meant that the working environment variable affected teachers' performance by $72.3 \%$. In comparison, the remaining $27.7 \%$ was influenced by other variables outside the model or variables not studied.

Table 2. R Correlation Coefficient Value

\begin{tabular}{cc}
\hline Interval Coefficient & Categorization \\
\hline $0.80-1.000$ & Very high \\
\hline $0.60-0.799$ & High \\
\hline $0.40-0.599$ & Medium \\
\hline $0.20-0.399$ & Low \\
\hline $0.00-0.199$ & Very low \\
\hline
\end{tabular}

Furthermore, the inferential statistics of hypothesis testing indicated that the significance test, if $\mathrm{t}_{\text {test }}<\mathrm{t}_{\text {table, }}$, could be concluded that $\mathrm{H}_{\mathrm{o}}$ was accepted, meaning that the regression equation constant was not significant. Meanwhile, if $t_{\text {test }}>t_{\text {table, }}$, it could be concluded that $\mathrm{H}_{\mathrm{o}}$ was rejected and $\mathrm{H}_{\mathrm{a}}$ was accepted, which meant that the regression coefficient was significant. The finding of this research obtained $t_{\text {test }}=26.146$ and $t_{\text {table }}=$ 1.812 for the $5 \%$ significance level. Because $t_{\text {test }}$ was greater than $t_{\text {table, }} H_{o}$ was rejected, and $\mathrm{H}_{\mathrm{a}}$ was accepted. Thus, it could be concluded that there was a significant influence between the working environment on teachers' performance at MTs Madani Pao-Pao.

A working environment supports teachers to improve their performance in conducting their duties at school. However, if the teachers' performance is lacking, the school needs to reevaluate the working environment. This statement is in line with the research conducted by Surya (2004) that the factors that influence the teachers' performance are the working environment. Meanwhile, in his research, Eliyanto (2018) showed that the working environment significantly influenced teachers' performance at 
Muhammadiyah high school in Kebumen Regency (Ernanto, 2014). Furthermore, in his dissertation, examined the relationship between the working environment and teacher commitment in elementary schools in Alabama found a connection between a good school environment and more teachers' commitment. Nevertheless, in their research, Hamsah, Syamsuddhuha, \& Rahman (2019) concluded that the work atmosphere affected teachers' performance at Madrasah Aliyah in Gantarang District. A conducive work atmosphere made the madrasah environment comfortable so that it would be one of the encouragements for teachers to conduct their duties properly. It was further said that the more conducive the work atmosphere was, the higher the teachers' performance. Therefore, the working environment aspect must be expanded by considering the physical and psychological school environment.

The physical and psychological working environment had influences on teacher performance. Kuncoro \& Dardiri (2017), in their research results, proved that there was a correlation between the working environment and performance, which meant that a good working environment included physical, psychological, and non-physical conditions that positively affected the psychological and professional performance of teachers.

The interesting thing with the findings was that the physical condition of MTs PaoPao was not yet conducive to support teaching and learning activities and providing a sense of comfort in working for the teachers. School buildings and a laboratory were used together with MI, MTs, and MA with randomized and unordered classes. The teachers' room mixed with staff illustrated that the working environment at school was less conducive to improving teachers' performance. It was in line with the research finding conducted by Elfita, Zulhaini, \& Mailani (2019). They found an influence between the physical working environment on the teachers' performance of Islamic Education at MTs Negeri Sentajo that affected teachers' performance in the working environment itself. However, other research conducted by Arianto (2013) showed that the working environment did not significantly influence teachers' performance at the Special Education Foundation in Demak Regency. The working environment, which was the benchmark in that study, was seen from the physical aspects of the school, which were school facilities and infrastructure that did not support teaching and learning activities. In the physical school that creates a working environment that was not conducive, teachers' performance was not affected. Improving the teachers' performance was supported by a strong work culture and ultimately could create a conducive working atmosphere to improve the quality of work.

Lack of school facilities also affects the teachers' performance. It is related to Arianto's research (2013) that if the working environment only looked at the physical conditions of the school and observed the effect on the teachers' performance, the results might not have a significant effect, especially school facilities and infrastructure in Indonesia was indeed unequal. Still, the quality of work provided by the teachers was quite good, so it would be very biased to conclude that physical conditions did not significantly affect the performance of teachers.

The psychological aspect includes providing a portion of the work to teachers, the 
suitability of teachers' educational background, competence and expertise to the subjects being taught, and the atmosphere or social relations between teachers and educational staffs. Teachers in MTs Madani Pao-Pao had assigned to teach subjects based on their educational background. The placement of teachers following their competence, expertise, and educational background and their efforts always strive to create and maintain a very conducive atmosphere and working environment that triggers the high morale of educators. In completing teachers' job, they have sufficient ability to teach well and be performed seriously. The work can be completed to represent their performance which is a positive and significant cause of the influence of the working environment on teachers' performance. The teachers' enthusiasm at work is triggered by a conducive working environment and a match between their educational background and experience with the placement of teachers based on their competence.

A good relationship among teachers, principal, educational staffs, and students affects teacher performance. This statement is in line with Herwanto, Ummi, Rustiana, \& Retna (2018) that the work environment is believed to affect the teacher's personality and impact other colleagues until it is finally reflected in the effectiveness of the teacher's performance. Therefore, this condition has implications for improving the work environment to improve teacher performance. It is then considered a need for workplace well-being. In this case, the teachers can feel comfortable in a supportive work environment so that the duties and responsibilities can be completed professionally.

The psychological working environment also influences teacher productivity. Therefore, schools are required to create a work environment that supports cooperation between elements within the school. It should at least be open and supportive so that teachers feel valued and supported. If the psychological aspect is not good, the teacher performance will be disrupted. On the other hand, a conducive work environment provides a sense of security and allows teachers to work optimally.

According to Bahri (2011), each teacher's performance is different due to the characteristics of each of these teachers. For example, teachers who have a desire to achieve tend to have optimal performance. However, the findings in this study need to be considered further because the teacher's performance is strongly influenced by the work environment, which means that if the teacher's work environment is still low, the teacher's performance will be less than optimal. Therefore, the teacher's work environment should be considered first because these factors play a role in the teacher's perception of the work being undertaken and the teacher's perception of the workplace.

The results of this study provided an initial overview for schools regarding the condition of the teachers working environment and other psychological aspects that affect teacher performance. MTs Madani Pao-Pao can use the findings in this study to improve the welfare of teachers in the workplace to improve performance and correct deficiencies in the teaching process.

Many factors were missed and not examined in this study. In addition, teacher performance is believed to be influenced by several other factors, both from the 
individual internal factors of the teacher and from other external factors. Therefore, several other factors contributing to teacher performance need to be investigated further to understand better. Further research is recommended to explore other physical and psychological variables to assess the teacher's performance, such as the principal, coteacher or student being taught. The development of research related to teacher performance and work-family conflict also still needs to be done to provide an overview of the condition of teachers in the field. Similar research related to this topic can also add insight and contribute to the development of science.

\section{CONCLUSION}

Based on the results of data analysis, the findings indicated a significant influence between the working environment and the teachers' performance at MTs. Madani PaoPao. It meant that if the working environment is more conducive, comfortable, safe, and enjoyable, the teachers' performance was also higher or more productive. The more productive teachers' performance would positively affect the teaching and learning process to positively impact students. The implication of this research is to inform the principal or leadership to provide a conducive, comfortable, and safe working environment to improve their teachers' performance.

\section{REFERENCES}

Arianto, D. A. N. (2013). Pengaruh Kedisiplinan, Lingkungan Kerja dan Budaya Kerja terhadap Kinerja Tenaga Pengajar. Jurnal Economia, 9(2), 191-200. https://doi.org/10.21831/economia.v9i2.1809.

Bahri, S. (2011). Faktor yang Mempengaruhi Kinerja Guru SD di Dataran Tinggimoncong Kabupaten Gowa Provinsi Selawesi Selatan. Jurnal Medtek, 3(2). http://eprints.uny.ac.id/id/eprint/49076.

Bernardin, H. J., \& Russel. (2010). Human Resourch Management. New York: McGraw-Hil.

Elfita, R., Zulhaini, \& Mailani, I. (2019). Pengaruh Lingkungan Kerja Terhadap Kinerja Guru Pendidikan Agama Islam di MTs Negeri Sentajo Filial Singingi Kecamatan Singingi Kabupaten Kuantan Singingi. Jurnal AL-HIKMAH, 1(1), 37-55. https://doi.org/10.32502/jimn.v6i2.1583.

Eliyanto. (2018). Pengaruh Motivasi Kerja dan Lingkungan Kerja Terhadap Kinerja Guru SMA Muhammadiyah di Kabupaten Kebumen. Jurnal Pendidikan Madrasah, 3(1), 169-181. https://doi.org/10.14421/jpm.2018.31-14.

Ernanto, B. S. (2014). Pekerja Anak, Pemulung Anak, TPA Benowo. Journal Unair, III(III), 1-13. http://journal.unair.ac.id/download-fullpapers-kmnts15f64d01eafull.pdf.

Fraenken, R., \& Wallen, B. (2009). How to Design and Evaluate Research in Education. New York: McGraw-Hil.

Hamsah, Syamsuddhuha, S., \& Rahman, U. (2019). Pengaruh iklim kerja terhadap kinerja guru pada madrasah aliyah di kecamatan gantarang kabupaten bulukumba. Jurnal Idaarah, 3(2), 236-244. https://doi.org/10.24252/idaarah.v3i2.10264.

Handayani, D. (2017). Pengaruh Pendidikan dan Pelatihan, Motivasi, serta Lingkungan 
Kerja terhadap Kinerja Guru SMK Negeri Banyuasin. Jurnal Ilmu Manajemen, 6(2), 140-150. https://doi.org/10.32502/jimn.v6i2.1583.

Herwanto, Ummi, F. T., Rustiana, D., \& Retna, P. (2018). Aspek-Aspek Psikologis yang Berpengaruh terhadap Kinerja Profesional Guru Sekolah Dasar (SD). Jurnal Penelitian Dan Pengukuran Psikologi, 7(2), 100-108. https://doi.org/10.21009/JPPP.072.07.

Kuncoro, T., \& Dardiri, A. (2017). Teacher Performance and Work Environment in the instructional Process in Vocational School. AIP Conference Proceedings, 1887(September). https://doi.org/10.1063/1.5003526.

Mangkunegara, A. A. A. P. (2004). Perencanaan dan Pengembangan Sumber Daya Manusia. Bandung: PT. Refika Aditama.

Rahmawanti, N. P., Swasto, B., \& Prasetya, A. (2014). Pengaruh Lingkungan Kerja terhadap Kinerja Karyawan (Studi pada Karyawan Kantor Pelayanan Pajak Pratama Malang Utara). Jurnal Administrasi Bisnis (JAB), 8(2), 1-9. http://administrasibisnis.studentjournal.ub.ac.id/index.php/jab/article/view/36 6.

Robbins, S. P. (2002). Perilaku Organisasi. Jakarta: Erlangga.

Sardiman. (2011). Interaksi dan Motivasi Pembelajaran. Jakarta: Rajawali Perss.

Sedarmayanti. (2011). Sumber Daya Manusia dan Efektifitas Kerja. Bandung: Mandar Maju.

Simanjuntak, B. (2003). Perilaku Organisasi. Yogyakarta: Remaja Rosdakarya.

Surya, Muhammad. (2004). Psikologi Pembelajaran dan Pengajaran. Bandung: Pustaka Bani Quraisy.

Suwatno dan Priansa, D. (2011). Manajemen SDM dalam Organisasi Publik dan Bisnis. Bandung: Alfabeta. 